\title{
THE IMPACT OF SOCIOECONOMIC CHARACTERISTICS AND LIFESTYLES ON VITAMIN D DEFICIT IN MENTALLY ILL PATIENTS
}

\author{
Sanja Kocic ${ }^{1,4}$, Svetlana Ristic ${ }^{2}$, Sandra Zivanovic ${ }^{3}$, Natasa Mihailovic ${ }^{4}$, Svetlana Curcic ${ }^{5}$ and Dragan Vasiljevic ${ }^{1,4}$ \\ ${ }^{1}$ Faculty of Medical Sciences, University of Kragujevac, Kragujevac, Serbia \\ ${ }^{2}$ Institute for Oncology and Radiology of Serbia, Belgrade, Serbia \\ ${ }^{3}$ Faculty of Hotel Management and Tourism in Vrnjacka Banja, University of Kragujevac, Vrnjaca Banja, Serbia \\ ${ }^{4}$ Institute of Public Health Kragujevac, Kragujevac, Srbija \\ ${ }^{5}$ Faculty of Education in Jagodina, University of Kragujevac, Jagodina, Srbija
}

\section{UTICAJ SOCIOEKONOMSIKIH KARAKTERISTIKA I NAČINA ŽIVOTA NA DEFICIT VITAMINA D KOD MENTALNO OBOLELIH PACIJENATA

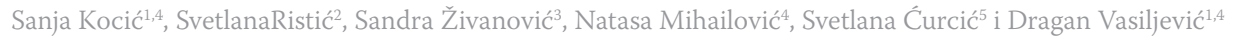 \\ ${ }^{1}$ Fakultet medicinskih nauka, Univerzitet u Kragujevcu \\ ${ }^{2}$ Institut za onkologiju i radiologiju Srbije \\ ${ }^{3}$ Fakultet za hotelijerstvo i turizam u Vrnjačkoj Banji \\ 4. Institut za javno zdravlje Kragujevac \\ ${ }^{5}$ Pedagoški fakultet u Jagodini, Univerzitet u Kragujevcu}

\begin{abstract}
Mental illnesses put patients at high risk for vitamin $D$ deficit. The aim of the research is to examine the impacts of socioeconomic characteristics and lifestyles on vitamin $D$ deficiency in mentally diseased patients. In this crosssectional study we used blood samples from patients who were treated for mental disorders at Specialist-consultative unit of the Health Center and Clinical Center Kragujevac from May-June 2014. The study used a questionnaire for the assessment of vitamin D status. The study included 220 subjects with different types of mental disorders. Normal values of vitamin $D$ were detected in $16 \%$ of patients whereas $64 \%$ of patients had vitamin D deficiency. The patients with vitamin D deficit were in average 3 years older than that but the difference is not statistically significant $(p>0.05)$. The patients with vitamin $D$ deficiency were primarily female ( $p=0.003)$, people with high-school education from urban environment who lived in bad life conditions $(p>0.05)$. Between patients with and without vitamin $D$ deficiency there is no difference in cigarette consumption, in the number of cigarettes per day, in alcohol usage, in coffee consumption and in nutrition. However, the patients without vitamin D deficiency spent more time outside; during the past year were more exposed to sun and during the past seven days spent more than 30 minutes a day exposed to sunlight $(p<0.01)$. These facts indicate that there is a current need for further research in this area.
\end{abstract}

Keywords: vitamin D, vitamin D defi ciency, mental disorders, lifestyle, socioeconomic characteristics

\section{SAŽETAK}

Mentalne bolesti su bitan faktor rizika za nastanak deficita vitamina D. Cilj ovog istraživanja je ispitivanje uticaja sociodemografskih karakteristika i načina života na deficit vitamina $D$ kod mentalno obolelih pacijenata. Istraživanje predstavlja studiju preseka u kojoj su ispitivani uzorci krvi pacijenata koji su, zbog mentalnih poremećaja, lečeni u specijalističko-konsultativnoj jedinici Zdravstvenog centra Kragujevac i Kliničkom centru Kragujevac tokom maja i juna 2014. godine. U istraživanju je korišćen upitnik za ispitivanje nivoa vitamina D. Istraživanje je obuhvatilo 220 ispitanika sa dijagnozom razlicitih mentalnih poremećaja. Fiziološke vrednosti vitamina D su izmerene kod $16 \%$ pacijenata, dok je njih $64 \%$ imalo deficit vitamina D. Pacijenti koji su imali deficit vitamina D su u proseku 3 godine stariji, ali ta razlika nije statistički značajna ( $p>0.05$ ). Među pacijentima sa nedostatkom vitamina D preovladuju osobe ženskog pola ( $p=0.003)$, osobe sa srednjim stepenom obrazovanja iz urbanog okruženja koje žive u lošim uslovima ( $p>0.05)$. U poređenju pacijenata sa $i$ bez deficita vitamina D nije bilo značajnih razlika u konzumiranju duvana, broju popušenih cigareta na dnevnom nivou, konzumiranju alkohola $i$ kafe, i načinu ishrane. Međutim, pacijenti koji nisu imali nedostatak vitamina $D$ su provodili više vremena napolju, tokom prethodne godine su se više izlagali sunčevom zračenju $i$ tokom prethodnih sedam dana su provodili više od 30 minuta napolju na sučevoj svetlosti (p<0.01). Navedene činjenice ukazuju na potrebu za daljim istraživanjima u ovoj oblasti.

Ključne reči: vitamin $D$, deficit vitamina $D$, mentalne bolesti, način života, socioekomoske karakteristike

\section{sciendo}

UDK: 615.356:577.161.2; 616.89-008.44(497.11)"2014"

Ser J Exp Clin Res 2019; 20 (1): 25-31

DOI: 10.1515/SJECR-2017-0026
Corresponding author: 


\section{INTRODUCTION}

According to the World Health Organization, at the beginning of the new millennium, there were 450 million people suffering from a mental illness or behavioral disorder in the world. About 33\% of their lifespan they lived with disability due to their neuropsychiatric disorder. Only the depression bears more than 10\% of YLD (Years Lived with Disability) (1).

In our country intense acute and chronic stress and accumulated trauma, which have affected all our society in the past two decades, due to wars and transition, had significant consequences on mental health. According to the Institute of Public Health of Serbia "Dr Milan Jovanović Batut", the number of mental and behavioral disorders has increased by $13.5 \%$ last ten years and their total morbidity and mortality are on the rise. Thus, these disorders are now the second biggest health problem of the population in Serbia after cardiovascular diseases (2).

Vitamin D is synthesized in the body from its precursor, 7-dehydrocholesterol, $80 \%$ of which is produced in skin under the influence of UV rays and $20 \%$ is taken orally through food and/or supplements. Vitamin D has pleiotropic effects and does not work like other vitamins only on biochemical processes. It regulates the transcription of a large number of genes and the synthesis of cellular proteins (3-5). Vitamin D deficiency causes rachitis and osteomalacia and increases the chances of developing osteoporosis, allergic and autoimmune diseases, hypertension, malignant diseases and mental disorders (6-11). Vitamin D receptors are found in neurons and glial cells which are mapped in areas of the brain that are responsible for the development of depression. This indicates the role of vitamin D in psychosomatic disorders (12-14). The antidepressant effect of vitamin $\mathrm{D}$ is achieved due to the impact it has on the hypothalamic-pituitary-adrenal interface which consequently regulates the production of adrenaline, noradrenaline and dopamine (15). Without any doubt, it is shown that its deficit causes cognitive disorders and depressive moods (12), but the results of the previous studies different (13).

\section{THE AIM OF WORK}

The aim of the research is to examine the impacts of sociodemographic characteristics and lifestyles on vitamin D deficiency in mentally diseased patients.

\section{MATERIAL AND METHODS}

\section{Study description}

This study was designed as a cross-sectional study. The study used blood samples of patients who were treated for a newly-diagnosed illness or in a stage of exacerbations (a relapse) of a chronic mental disease. All patients gave their consent to be included in the study. Patients were treated at Specialist-consultative unit of the Department of Neuropsychiatry of Health Centre Kragujevac and at the Clinic of Psychiatry, Clinical Centre Kragujevac from May - June 2014. Both outpatient and inpatient cases were included. The participants had the following characteristics: adults of both sexes aged from 19 to over 81 years. Their psychiatric diagnoses include the following mental disorders: organic and symptomatic mental disorders, mental and behavioural disorders caused by psychoactive substances, schizophrenia, schizotypal and delusional disorders, mood disorders, neurotic stress-related and somatoform disorders, syndromes of disturbed behaviour associated with physiological disturbances and physical factors, personality disorders and behavioural disorders, mental retardation, developmental disorders of the psyche (F00-F89), epilepsy (G80) and poisoning suicide attempts (T42) with antiepileptic, sedative-hypnotic and anti-parkinsonian drugs. The study was approved by the Ethics Committees of the Clinical Centre Kragujevac and the Health Centre Kragujevac.

The patients with the following characteristics were excluded: patients who were younger than 18 years, patients with diseases of a liver and kidneys, patients with tumourinduced osteomalacia, patients with hyperthyroidism, hyperparathyroidism, granulomatous disorders, sarcoidosis or tuberculosis; those who refused to participate in the study or were prevented from participating by any other circumstance were also not included.

The assessment of a mental status of patients was obtained by examining the medical (psychiatric) documenta tion that was previously made by a competent psychiatrist. The study used a questionnaire for the assessment of vitamin D status (16) which was adapted to the needs of this research. It consists of segments related to: demographic characteristics of the respondents, history of a present illness, personal medical history, psychiatric status, habits of respondents in terms of diet, sun exposure, physical activity, bad habits (smoking and alcohol) and personal and family history.

In order to eliminate geographical and seasonal differences, i.e. the different degrees of sunshine, all respondents came from a single, narrow geographic area (territory of Kragujevac and the surrounding area - northern latitude of the city of Kragujevac is $\left.44^{\circ} 22^{\prime}\right)$. Also, the blood samples were collected during the same season.

The dependent variable was the concentration of vitamin $\mathrm{D}$ in the form of $25(\mathrm{OH})$ within the serum. The defined cut-off for vitamin D deficiency is $<12 \mathrm{ng} / \mathrm{ml}$, the inadequacy ranges from $12-20 \mathrm{ng} / \mathrm{ml}$, and normal values are above $20 \mathrm{ng} / \mathrm{ml}$ (17). The study population was divided into two groups: the first with the serum $25(\mathrm{OH}) \mathrm{D}<12 \mathrm{ng} /$ $\mathrm{ml}$ and the other with $25(\mathrm{OH}) \mathrm{D}>12 \mathrm{ng} / \mathrm{ml}$.

\section{Statistical analysis}

For the harmonization of sampling distribution with a normal distribution, we used Normal Q-Q Plot and Histogram charts and Kolmogorov-Smirnov and Shapiro-Wilk tests. In order to describe the parameters of significance 

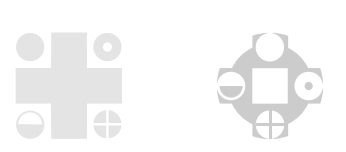

Table 1. Deficiency of vitamin D and demographic characteristics of the subjects

\begin{tabular}{|c|c|c|c|c|}
\hline \multirow[b]{2}{*}{ Demographic characteristics } & \multirow[b]{2}{*}{ Total } & \multicolumn{2}{|c|}{$25(\mathrm{OH}) \mathrm{D}$ status } & \multirow[b]{2}{*}{ Test } \\
\hline & & $\begin{array}{l}\text { Deficiency } \\
<12 \mathrm{ng} / \mathrm{ml}\end{array}$ & $\begin{array}{l}\text { Without deficiency } \\
\qquad>12 \mathrm{ng} / \mathrm{ml}\end{array}$ & \\
\hline \multicolumn{5}{|c|}{ Sex } \\
\hline Male & $72(32.7 \%)$ & $36(25.71 \%)$ & $36(60.0 \%)$ & \multirow{2}{*}{$\mathrm{p}=\mathbf{0 . 0 0 3}$} \\
\hline Female & $148(67.3 \%)$ & $104(74.29 \%)$ & $44(40.0 \%)$ & \\
\hline \multicolumn{5}{|c|}{ Age } \\
\hline Mean $( \pm$ SD $)$ & $48.68( \pm 13.3)$ & $49.66( \pm 13.63)$ & $46.98( \pm 12.59)$ & \multirow{2}{*}{$\mathrm{p}=0.370$} \\
\hline Median (Range) & $49(19-81)$ & $49(21-81)$ & $49(19-71)$ & \\
\hline \multicolumn{5}{|c|}{ Education } \\
\hline No education & $2(0.91 \%)$ & $2(1.43 \%)$ & $0(0 \%)$ & \multirow{6}{*}{$\mathrm{p}=0.781$} \\
\hline Incomplete primary & $11(5.00 \%)$ & $6(4.29 \%)$ & $5(6.25 \%)$ & \\
\hline Primary education & $45(20.45 \%)$ & $30(21.43 \%)$ & $15(18.75 \%)$ & \\
\hline Secondary education & $140(63.64 \%)$ & $86(61.43 \%)$ & $54(67.5 \%)$ & \\
\hline High education & $9(4.09 \%)$ & $6(4.29 \%)$ & $3(3.75 \%)$ & \\
\hline University education & $13(5.91 \%)$ & $10(7.14 \%)$ & $3(3.75 \%)$ & \\
\hline \multicolumn{5}{|c|}{ Residence } \\
\hline Urban & $175(79.55 \%)$ & $114(81.43 \%)$ & $61(76.25 \%)$ & \multirow{3}{*}{$\mathrm{p}=0.305$} \\
\hline Rural & $44(20.00 \%)$ & $25(17.86 \%)$ & $19(23.75 \%)$ & \\
\hline No data available & $1(0.45 \%)$ & $1(0.71 \%)$ & $0(0 \%)$ & \\
\hline \multicolumn{5}{|c|}{ Living conditions } \\
\hline Good & $61(27.73 \%)$ & $34(24.29 \%)$ & $27(33.75 \%)$ & \multirow{4}{*}{$\mathrm{p}=0.322$} \\
\hline Medium & $75(34.09 \%)$ & $50(35.71 \%)$ & $25(31.25 \%)$ & \\
\hline $\mathrm{Bad}$ & $81(36.82 \%)$ & $54(38.57 \%)$ & $27(33.75 \%)$ & \\
\hline No data & $3(1.36 \%)$ & $2(1.43 \%)$ & $1(1.25 \%)$ & \\
\hline Total & $220(100 \%)$ & 140 (100\%) & $80(100 \%)$ & \\
\hline
\end{tabular}

depending on their nature we used the measures of descriptive statistics: frequency, percentage, mean (average), median, \pm standard deviation (SD) and scope (range). For the level of statistical significance we chose the value of $\alpha=0.05$. In testing the difference between independent groups depending on the nature of the investigated parameters we used: Pearson $X^{2}$ test, Fisher exact test and MannWhitney test. $X^{2}$ agreement test was used to examine the concordance of the results obtained through this study with the referent results. The data analysis was performed in the statistical program SPSS version 19.0.

\section{RESULTS}

The study included 220 subjects with different types of mental disorders. 135 (61\%) patients were treated at the Psychiatric Clinic of Clinical Centre Kragujevac and 85 (39\%) at Psychiatric Department of Health Centre Kragujevac. More than a half, namely 135 patients (61\%) were treated at the Psychiatric Clinic of Clinical Center Kragujevac and 85 (39\%) at Psychiatric Department of Health Center Kragujevac. Moreover, 88 patients (40\%) were included in the inpatient service and $132(60 \%)$ in outpatient service. Normal values of vitamin D level were detected in $16 \%$ of the patients and $64 \%$ had vitamin D deficiency.

Three quarters of the total number of respondents were women so the distribution in terms of gender differs significantly from what was expected $\left(\chi_{1}{ }_{1}=8.60, \mathrm{p}=0.003\right)$.
The mean age was 49 years. The youngest subject was at the beginning of the adult age while the oldest belonged to the category of very old people. People with vitamin $\mathrm{D}$ deficiency were on average about three years older but the difference is not statistically significant $(\mathrm{p}=0.370)$. More than a half of respondents completed secondary school, a quarter of them had primary or incomplete primary education while there was the lowest number of subjects with higher or high education. Most of the respondents lived in an urban environment and the largest number, regardless of the place of residence, lived in bad living conditions. The number of respondents who lived in poor conditions is higher in the group with vitamin $D$ deficiency $(\mathrm{p}=0.322)$ (Table 1$)$.

Smokers made $55 \%$ of the total number of subjects. In average, they smoked one pack a day. Most subjects did not use alcohol (85\%), and only $8 \%$ did not drink coffee. Most subjects who drank coffee intensively (more than two cups a day) were in the group with no vitamin $\mathrm{D}$ deficit $(\mathrm{p}=0.248)$ (Table 2).

During the day, $68 \%$ of the subjects were physically active and $77.5 \%$ of them had no vitamin D deficit. The subjects were active for about 5 hours a day in average - the group without the deficit for 5.75 hours and the group with a deficit for 4.42 hours $(\mathrm{p}=0.005) .6 \%$ of the subjects did exercises and all of them had no vitamin D deficit ( $\mathrm{p}=0.007)$. Subjects exercised 3.8 times per week in average; most commonly those without the deficit (4.3 times a week) but the difference is not statistically significant $(\mathrm{p}=0.077)$. 


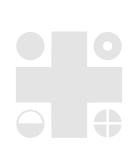

Table 2. Vitamin D deficiency and bad habits (smoking, alcohol and coffee consumptions)

\begin{tabular}{|c|c|c|c|c|}
\hline \multirow[b]{2}{*}{ Bad habits } & \multirow[b]{2}{*}{ Total } & \multicolumn{2}{|c|}{$25(\mathrm{OH}) \mathrm{D}$ status } & \multirow[b]{2}{*}{ Test } \\
\hline & & $\begin{array}{l}\text { Deficiency } \\
<12 \mathrm{ng} / \mathrm{ml}\end{array}$ & Without deficiency $>12 \mathrm{ng} / \mathrm{ml}$ & \\
\hline \multicolumn{5}{|c|}{ Smoking } \\
\hline Yes & $122(55.45 \%)$ & $72(51.43 \%)$ & $50(62.5 \%)$ & \multirow{4}{*}{$\mathrm{p}=0.128$} \\
\hline No & 87 (39.55\%) & $62(44.29 \%)$ & $25(31.25 \%)$ & \\
\hline Earlier & $10(4.55 \%)$ & $5(3.57 \%)$ & $5(6.25 \%)$ & \\
\hline No data & $1(0.71 \%)$ & $0(0 \%)$ & $1(0.45 \%)$ & \\
\hline \multicolumn{5}{|c|}{ Number of cigarettes a day } \\
\hline Mean $( \pm \mathrm{SD})$ & $21.49( \pm 15.05)$ & $22.08( \pm 17.04)$ & $20.75( \pm 12.25)$ & \multirow{2}{*}{$\mathrm{p}=0.994$} \\
\hline Median (Range) & $20(1-80)$ & $20(2-80)$ & $20(1-50)$ & \\
\hline \multicolumn{5}{|c|}{ Alcohol } \\
\hline No & $186(84.55 \%)$ & $122(87.14 \%)$ & $64(80 \%)$ & \multirow{5}{*}{$\mathrm{p}=0.096$} \\
\hline Yes, not every day & $19(8.64 \%)$ & $8(5.71 \%)$ & $11(13.75 \%)$ & \\
\hline Yes, two glasses a day & $1(0.45 \%)$ & $0(0 \%)$ & $1(1.25 \%)$ & \\
\hline Yes, more than two glasses a day & $13(5.91 \%)$ & $9(6.43 \%)$ & $4(5 \%)$ & \\
\hline No data & $1(0.45 \%)$ & $1(0.71 \%)$ & $0(0 \%)$ & \\
\hline \multicolumn{5}{|c|}{ Coffee } \\
\hline Intensively & $75(34.09 \%)$ & $43(30.71 \%)$ & $32(40 \%)$ & \multirow{4}{*}{$\mathrm{p}=0.248$} \\
\hline Moderate & $126(57.27 \%)$ & $82(58.57 \%)$ & $44(55 \%)$ & \\
\hline No & $18(8.18 \%)$ & $14(10 \%)$ & $4(5 \%)$ & \\
\hline No data & $1(0.45 \%)$ & $1(0.71 \%)$ & $0(0 \%)$ & \\
\hline Total & $220(100 \%)$ & $140(100 \%)$ & $80(100 \%)$ & \\
\hline
\end{tabular}

Table 3. Vitamin D deficiency and sun exposure

\begin{tabular}{|c|c|c|c|c|}
\hline \multirow[b]{2}{*}{ Sun exposure } & \multirow[b]{2}{*}{ Total } & \multicolumn{2}{|c|}{$25(\mathrm{OH}) \mathrm{D}$ status } & \multirow[b]{2}{*}{ Test } \\
\hline & & $\begin{array}{l}\text { Deficiency } \\
<12 \mathrm{ng} / \mathrm{ml}\end{array}$ & $\begin{array}{l}\text { Without deficiency } \\
>12 \mathrm{ng} / \mathrm{ml}\end{array}$ & \\
\hline \multicolumn{5}{|c|}{ Being outdoors long } \\
\hline Yes & 75 (34.09\%) & 37 (26.43\%) & $38(47.5 \%)$ & \multirow{3}{*}{$\mathrm{p}=\mathbf{0 . 0 0 1}$} \\
\hline No & $144(65.45 \%)$ & $102(72.86 \%)$ & $42(52.5 \%)$ & \\
\hline No data & $1(0.45 \%)$ & $1(0.71 \%)$ & $0(0 \%)$ & \\
\hline \multicolumn{5}{|c|}{ Sun exposure during the last year } \\
\hline Yes & $128(58.18 \%)$ & $71(50.71 \%)$ & $57(71.25 \%)$ & \multirow{2}{*}{$\mathrm{p}=\mathbf{0 . 0 0 2}$} \\
\hline No & $92(41.81 \%)$ & $69(49.28 \%)$ & $23(28.75 \%)$ & \\
\hline \multicolumn{5}{|c|}{ Sun exposure during the last week } \\
\hline$<5$ minutes a day & $76(34.55 \%)$ & $55(39.29 \%)$ & $21(26.25 \%)$ & \multirow{4}{*}{$\mathrm{p}=\mathbf{0 . 0 0 2}$} \\
\hline $5-15$ minutes a day & $6(2.73 \%)$ & $4(2.86 \%)$ & $2(2.5 \%)$ & \\
\hline $15-30$ minutes a day & $44(20 \%)$ & $34(24.29 \%)$ & $10(12.5 \%)$ & \\
\hline$>30$ minutes a day & $94(42.73 \%)$ & $44(33.57 \%)$ & 47 (58.75\%) & \\
\hline
\end{tabular}

Less respondents (34\%) spent time outside (exposed to sun) and most of them belonged to the group without the deficit of the vitamin $\mathrm{D}(\mathrm{p}=0.001)$. During the previous year, more than a half subjects had exposed themselves to sun with higher percentage in the group without the deficit $(\mathrm{p}=0.002)$. Most subjects who had spent less than five minutes during the previous week belonged to the group with the deficit. Most subjects had spent more than 30 minutes outside during the past week and most of them belonged to the group without the deficit ( $\mathrm{p}=0.002)$ (Table 3 ).

The question about regular diet (3 meals, 2 fruit snacks and consumption of fruit and vegetables every day) was answered affirmatively by $16 \%$, negatively by $64 \%$, while $20 \%$ of the subjects stated that they eat regularly at times. There is not statistically significant difference between groups with and without deficiency in terms of regular nutrition $(\mathrm{p}=0.145)$.

\section{DISCUSSION}

New epidemiological data show that about billion people worldwide, including North America and Europe, have vitamin D deficiency $(18,19)$. Such results are most commonly explained by the fact that nutrition is poor with vitamins and that exposure to sun is low $(20,21)$. Mental illnesses put patients at high risk for vitamin D deficiency. It is very likely that a mental illness disrupts the socioeconomic conditions that are required for optimal vitamin D levels, especially in terms of nutrition and healthy lifestyles like physical activity and sun exposure. New studies indicate that certain meidcines used in the treatment of mental illnesses deepen the deficit of the vitamin D (22). A systematic review of 14 epidemiological studies shows that the prevalence of low vitamin D values is about $30 \%$ 
higher in people with depression, who during the course of the disease are more than twice more likely to develop $\mathrm{D}$ hypovitaminosis than people in the general population (23). The results of the most recent meta-analysis indicate that two-thirds of patients with schizophrenia have values of vitamin D in the serum which can be classified as clinically significant deficit and that such people are about two times more likely to develop schizophrenia (24). Our study confirms the findings of earlier studies that the presence of mental disorders (mostly depression and schizophrenia) is associated with clinically significant deficiency of vitamin $\mathrm{D}$, but with a much higher prevalence (25).

Two main factors responsible for the occurrence of vitamin D deficiency are insufficient exposure to sunlight and/or inadequate nutritional intake of vitamin D. In addition, it has been proven that there are numerou factors that contribute to this phenomenon: age, skin type, body mass index (BMI), geographic areas of residence, gender, and the usage of creams with SPF (26-28). Although the sex is often insignificant variable for the occurrence of vitamin D deficiency, low levels of vitamin D in women are explained by higher fat content in women which affects the formation of a depot of vitamin D in the body (29). In women during pregnancy and immediately after giving birth, who had depression, low levels of vitamin D were significantly associated with the severity of depressive symptoms (30). Low levels of vitamin D during pregnancy are actually identified as a risk factor for the development of postpartum depression (31). In our research, most patients with vitamin D deficiency are women and the difference between genders is statistically significant. The average age indicates that the majority of our respondents were at the end of the fifth decade of life. Older people have vitamin D deficiency more frequently $(32,33)$. The study, which involved over 1,500 people aged 60 and more, found that each fifth person had moderate or severe deficiency of vitamin $D$, close to half of them had depressive symptoms and their vitamin D levels were significantly lower than in other subjects (34). Low levels of vitamin D represent a marker of poor health status in this population and vitamin D supplementation in the elderly can reduce the overall mortality rate (35).

Three quarters of our subjects lived in urban areas in bad or satisfying conditions and most had secondary education. Large multicentric study conducted in several countries indicated that inferior material situation, higher costs for housing, lower levels of education, female gender and divorce are important factors associated with the presence of depression (36). In our study, the highest percentage of respondents who live in rural areas had no deficit of vitamin $\mathrm{D}$ which is in line with data from the literature that children and adults who are exposed to sun and who live in rural areas have better vitamin D status, especially in the summer months (37).

It is well known that smoking is associated with lower vitamin D levels. The level of vitamin D was significantly lower in smokers than in nonsmokers (38). In our study, a little over half of the respondents were smokers. The larg- est number of them consumed about one pack of cigarettes a day, and they started smoking in twenty-first year of life in average. These data are in accordance with the wellknown fact that smoking is significantly present in people with mental illnesses. Accordingly, the surprising fact is that in our study the group without vitamin D deficit had more smokers.

Almost all respondents regularly consumed coffee, mostly one cup a day. A high intake of caffeine, 4 or more cups a day, is a significant risk factor for insufficiency of vitamin D $(39,40)$.

Data from the literature suggests that lower levels of vitamin $\mathrm{D}$ were measured in patients being treated for alcohol dependence (41). This research shows that $85 \%$ of the subjects never consumed alcohol which was expected due to the fact that patients used psychotropic drugs. The amount of vitamin $\mathrm{D}$ that is generated in the skin depends on the level of melanin which is excellent absorber of UVB radiation (42). As latitude increases, the amount of UVB radiation decreases and there are more seasonal variations in UVB radiation (43). In our region from May to October it is sufficient to spend 5 to 15 minutes exposed to sun (1000 - 2000 IU is being created) (27). However, the analysis shows that there is a statistically significant difference in the time spent outdoors being exposed to sun during past year and week between patients with and without a deficiency of vitamin D.

Vitamin D deficiency in patients with somatic and mental illnesses is actually the result of the underlying disease (44). Physical exercise acts as a mild protective factor for the development of depressive disorders $(45,46)$. In our study, more than a half of the respondents said that they had certain physical activity, but only a small number of them did exercises. Some of the factors that contribute to such inactivity are certainly working disengagement and antipsychotic medications with extrapyramidal side effects which can be very severe (47).

Poor diet and the lack of sun exposure are common in patients with psychiatric disorders. Both factors play a significant role in the development of vitamin $\mathrm{D}$ deficiency (48). Analyzing consumer habits in terms of diet, we have found that more than half of the respondents in our study population did not care about proper nutrition. In recent years, recommendations for vitamin D intake increased significantly so it is difficult to meet such demands them only through diet (49). In our study population respondents practically did not use supplements of vitamin D.

\section{CONCLUSION}

Based on the presented results we may say that this study has contributed to better understanding of the role of vitamin $D$ in patients suffering from mental disorders. Lack of vitamin $\mathrm{D}$ could be potentially solved through publichealth measures relating to changes in the general lifestyle, a higher exposure to the sun and better nutrition. They all 
belong to the field of preventive medicine. Mental health care must be a necessary and important aspect of overall health care and public health systems. Mental disorders affect the functioning of individuals, causing emotional distress, impairment of life quality, alienation, stigma and discrimination. Their influence extends to the entire community and represents an enormous social and economic burden. In general, the question of the true nature of the relations between vitamin $\mathrm{D}$ and mental illnesses is still not sufficiently clarified. It is not clear whether the existence of mental illness primarily defines vitamin D deficiency (eg, disorders of nutrition, physical activity, stay in the open air, etc.) or, conversely, a low concentration of vitamin triggers or contributes to pathophysiological mechanisms of development of a psychiatric illness, and if the answer is affirmative, to what extent. Also, the question remains whether and to what extent therapeutic interventions in psychiatry, especially the application of relevant psychotropic medications, affect the disorders of homeostasis of vitamin D (22). These facts point to a current need for further research in this area, which should focus on identifying the causes of lack of vitamin D and its role in improving overall health of persons with mental disorders (23).

\section{ACKNOWLEDGMENTS}

This work was supported by grant from the Faculty of Medical Sciences, University of Kragujevac (project JP 13-14).

\section{REFERENCES}

1. Backovic D. Mental health and mental hygiene between two millenniums. Medical Review 2010; 63(11-12): 833-838.

2. Tosevski DL, Gajic SD, Milovancevic MP. State of psychiatry in Serbia-problems, advances and perspectives. Int. Rev. Psychiatry 2012; 24(4): 341-346.

3. Marusic G, Jeremic D, Vojinov S, Filipovic N, Popov M. Vitamin D and prostate cancer. Med. Pregl. 2013; 66 (5-6): 259-262.

4. Reichrath J, Lehmann B, Carlberg C, Varani J, Zouboulis CC. Vitamins as hormones. Horm. Metab. Res. 2007; 39: 71-84.

5. Holick MF. Vitamin D: importance in the prevention of cancers, type 1 diabetes, heart disease and osteoporosis. Am. J. Clin. Nutr. 2004; 79: 362-371.

6. Kavaric S, Vuksanovic M, Bozovic D, Jovanovic M, Jeremic V, Radojicic Z, et al. Body weight and waist circumference as predictors of vitamin D deficiency in patients with type 2 diabetes and cardiovascular disease. Vojnosanit. Pregl. 2013; 70(2): 163-169.

7. Holick MF. Sunlight and vitamin D: Both good for cardiovascular health. Journal of General Internal Medicine 2002; 17(9): 733-735.
8. Chen TC, Chimeh F, Lu Z, Mathieu J, Person KS, Zhang A, et al. Factors that influence the cutaneous synthesis and dietary sources of vitamin D. Arch. Biochem. Biophys. 2007; 460(2): 213-217.

9. Radlovic N, Mladenovic M, Simic D, Radlovic P. Vitamin D in the light of current knowledge. Srp. Arh. Celok. Lek. 2012; 140(1-2): 110-114.

10. Schmitz KJ, Skinner HG, Bautista LE, Fingerlin TE, Langefeld CD, Hicks PJ, et al. Association of 25-hydroxyvitamin $\mathrm{D}$ with blood pressure in predominantly 25-hydroxyvitamin D deficient Hispanic and African Americans. Am. J. Hypertens. 2009; 22(8): 867-870.

11. Antico A, Tampoia M, Tozzoli R, Bizzaro N. Can supplementation with vitamin $D$ reduce the risk or modify the course of autoimmune diseases? A systematic review of the literature. Autoimmun. Rev. 2012; 12(2): 127-136.

12. Naumovic N. Vitamin D: physiological importance. Medical Review 2010; 63(5-6): 301-304.

13. Kjærgaard M, Waterloo K, Wang CE, Almås B, Figenschau Y, Hutchinson MS, et al. Effect of vitamin D supplement on depression scores in people with low levels of serum 25-hydroxyvitamin D: nested cas-control study and randomised clinical trial. Br. J. Psychiatry 2012; 201: 360-368.

14. Ganji V, Milone C, Cody MM, McCarty F, Wang YT. Serum vitamin D concentrations are related to depression in young adult US population: the Third National Health and Nutrition Examination Survey. Int. Arch. Med. 2010; 3: 29.

15. Spedding S. Vitamin D and depression: a systematic review and meta-analysis comparing studies with and without biological flaws. Nutrients 2014; 6(4): 1501-1518.

16. Bolek-Berquist J, Elliott ME, Gangnon RE, Gemar D, Engelke J, Lawrence SJ, et al. Use of a Questionnaire to Assess Vitamin D Status in Young Adults. Public Health Nutr. 2009; 12(2): 236-243.

17. Ross AC, Taylor CL, Yaktine AL, Del Valle HB (2011). Dietary Reference Intakes for Calcium and Vitamin D. Washington, DC: National Academy Press.

18. Ramagopalan S, Heger A, Berlanga A, Maugeri N, Lincoln M, Burrell A, et al. A ChiP-seq defined genomewide map of vitamin $\mathrm{D}$ receptor binding: associations with disease and evolution. Genome Res. 2010; 20(10): 1352-1360.

19. Aung T, Chandina S, D'Silva K, Dimitrov N. The role of vitamin D in breast cancer. Oncol. Rev. 2009; 3: 19-25.

20. Berry D, Hypponen E. Determinants of vitamin D status: focus on genetic variations. Curr. Opin. Nephrol. Hypertens. 2011; 20: 331-336.

21. Dusso A, Brown A, Slatopolsky E.Vitamin D. Am. J. Physiol. Renal Physiol. 2005; 289: F8-F28.

22. Milovanovic DR, Janjic V, Zornic N, Djukic Dejanovic S, Jankovic SM. Risperidone-associated hypocalcemia. Am. J. Psychiatry 2010; 167: 1533-1534. 
23. Anglin RES, Samaan Z, Walter SD, McDonald SD. Vitamin D deficiency and depression in adults: systematic review and meta-analysis. Br. J. Psychiatry 2013; 202: 100-107.

24. Valipour G, Saneei P, Esmaillzadeh A. Serum vitamin D levels in relation to schizophrenia: a systematic review and meta-analysis of observational studies. J. Clin. Endocrinol. Metab. 2014; 99(10): 3863-3872.

25. Merlo C, Ross C, Trummler M, Zeller A. Prevalence and symptoms of vitamin D deficiency in general practices. Praxis (Bern 1994). 2012; 101(22): 1417-1422.

26. Engelsen O, Brustad M, Aksnes L, Lund E. Daily duration of vitamin D synthesis in human skin with relation to latitude, total ozone, altitude, ground cover, aerosols and cloud thickness. Photochem. Photobiol. 2005; 81(6): 1287-1290.

27. Engelsen $O$. The relationship between ultraviolet radiation exposure and vitamin D status. Nutrients 2010; 2(5): 482-495.

28. Tsiaras WG, Weinstock MA. Factors influencing vitamin D status. Acta Derm. Venereol. 2011; 91(2): 115-124.

29. Hovsepian S, Amini M, Aminorroaya A, Amini P, Iraj B. Prevalence of Vitamin D Deficiency among Adult Population of Isfahan City, Iran J. Health Popul. Nutr. 2011; 29(2): 149-155.

30. Gur EB, Gokduman A, Turan GA, Tatar S, Hepyilmaz I, Zengin EB, et al. Mid-pregnancy vitamin D levels and postpartum depression. Eur. J. Obstet. Gynecol. Reprod. Biol. 2014; 179C: 110-116.

31. Robinson M, Whitehouse AJ, Newnham JP, Gorman S, Jacoby P, Holt BJ, et al. Low maternal serum vitamin D during pregnancy and the risk for postpartum depression symptoms. Arch. Womens Ment. Health 2014; 17(3): 213-219.

32. Verhoeven V, Vanpuyenbroeck K, Lopez-Hartmann M, Wens J, Remmen R.Walk on the sunny side of life-epidemiology of hypovitaminosis $\mathrm{d}$ and mental healthin elderly nursing home residents. Journal of Nutrition, Health and Aging 2012; 16(4): 417-420.

33. Chan R, Woo J. The value of vitamin d supplementation in older people. Nutritional Therapy and Metabolism. 2011; 29(1): 8-21.

34. Lapid MI, Cha SS, Takahashi PY. Vitamin D and depression in geriatric primary care patients. Clin. Interv. Aging 2013; 8: 509-514.

35. Autier P, Boniol M, Pizot C, Mullie P. Vitamin D status and illhealth: a systematic review. Lancet Diabetes Endocrinol. 2014; 2(1): 76-89.

36. Rai D, Zitko P, Jones K, Lynch J, Araya R. Country-and individual-level socioeconomic determinants of depression: multilevelcross-national comparison. Br. J. Psychiatry 2013; 202(3): 195-203.
37. Trilok Kumar G, Chugh R, Eggersdorfer M. Poor Vitamin D Status in Healthy Populations in India: A Review of Current Evidence. Int. J. Vitam. Nutr. Res. 2015; 85(3-4): 185-201.

38. Ren W, Gu Y, Zhu L, Wang L, Chang Y, Yan M, et al. The effect of cigarette smoking on vitamin D level and depression in male patients with acute ischemic stroke. Compr. Psychiatry 2016; 65: 9-14.

39. Hallström H, Wolk A, Glynn A, Michaëlsson K. Coffee, tea and caffeine consumption in relation to osteoporotic fracture risk in a cohort of Swedish women. Osteoporos. Int. 2006; 17(7): 1055-1064.

40. Cosman F, De Beur SJ, LeBoff MS, Lewiecki EM, Tanner B, Randall S et al. Osteoporos. Int. 2014; 25(10): 2359-2381.

41. Schneider B, Weber B, Frensch A, Stein J, Fritz J. Vitamin D in schizophrenia, major depression and alcoholism. J. Neural. Transm. 2000; 107(7): 839-842.

42. $\overline{\text { Clemens }}$ TL, Adams JS, Henderson SL, Holick MF. Increased skin pigmentreduces the capacity of skin to synthesise vitamin D3. Lancet 1982; 1(8263): 74-76.

43. Holick MF. Medical progress: Vitamin D deficiency. N. Engl. J. Med. 2007; 357(3): 266-81.

44. Glendenning P. Measuring vitamin D. Australian prescriber First published online: 24 November 2014 Glendenning P. Measuring vitamin D. Aust. Prescr. 2015; 38: 12-15.

45. Cooney GM, Dwan K, Greig CA, Lawlor DA, Rimer J, Waugh FR, et al. Exercise for depression. Cochrane Database Syst. Rev. 2013; 12(9): CD00436.

46. Krogh J, Speyer H, Norgaard HC, Moltke A, Nordentoft M. Can exercise increase fitness and reduce weight in patients with schizophrenia and depression? Front. Psychiatry 2014; 28(5): 89.

47. Pesic G (2011). Antipsychotics. In Janković SM (Ed). Pharmacology and Toxicology (pp. 205-216). (3th ed.) Kragujevac: Medical faculty.

48. Koster JB, Kühbauch BA.Vitamin D deficiency and psychiatric patients. Tijdschr Psychiatr. 2011; 53(8): 561-565.

49. Schmid A, Walther B. Natural vitamin D content in animal products. Adv. Nutr. 2013; 4(4): 453-462. 